\title{
Biogeographic trends of endemic and subendemic flora in the western Iberian Peninsula under scenarios of future climate change
}

\author{
João Rocha (*), Rubim Almeida da Silva (*), Francisco Amich (**), \\ Álvaro Martins (***), Paulo Almeida (***), José T. Aranha (****), \\ Isabel García-Cabral (***), Mónica Martins (***), Carlos Castro (*****) \\ \& António L. Crespí (***)
}

\begin{abstract}
Rocha, J., Almeida da Silva, R., Amich, F., Martins, A., Almeida, P., Aranha, J.T., García-Cabral, I., Martins, M., Castro, C. \& Crespí, A.L. Biogeographic trends of endemic and subendemic flora in the western Iberian Peninsula under scenarios of future climate changes. Lazaroa 35: 19-35 (2014).

Altitude, temperature and precipitation are important environmental variables for the distribution of endemic plants. Taking in account their present distribution, this work studies the distribution trends of 116 endemic and subendemic species that occur on the western Iberian Peninsula and north-western Morocco, in different scenarios of future climate change. It was possible to identify five groups of taxa in the present environmental conditions, four of which for the northern part of the Iberian Peninsula. This range can partially be explained by the altitudinal variability of such area. The other group distributes along the western of the Iberian Peninsula. Concerning future climate change scenarios, important changes in species distribution, and a general south-north trend were obtained. Under harsher climatic changes, only the groups that tolerate the most variable environmental conditions persist. Estimates of extinction rates of the studied taxa for the next 75 years are also presented. The present methodology allows the application of ecological indicators (environmental groups, in this case) to understand biogeographic trends.
\end{abstract}

Keywords: Species distribution models, environmental variability, Maxent, conservation.

Resumen: Rocha, J., Almeida da Silva, R., Amich, F., Martins, A., Almeida, P., Aranha, J.T., García-Cabral, I., Martins, M., Castro, C. \& Crespí, A.L. Tendencias biogeográficas de flora endémica y subendémica en el oeste de la Península Ibérica bajo escenarios de cambio climático futuro. Lazaroa 35: 19-35 (2014).

Altitud, temperatura y precipitación son variables ambientales importantes en la circunscripción de las distribuciones biogeográficas de plantas endémicas. Tomando en cuenta su distribución actual, este trabajo estudia las tendencias de distribución de 116 especies endémicas y subendémicas que se producen en el oeste de la Península Ibérica y el noroeste de Marruecos, en diferentes escenarios de cambio climático futuro. Se identificaron cinco grupos de taxones en las actuales condiciones ambientales, de las cuales cuatro son para el norte de la Península Ibérica. Este rango se puede explicar parcialmente por la variabilidad altitudinal de dicha zona. El otro grupo se distribuye a lo largo del oeste de la Península Ibérica. En cuanto a los futuros escenarios de cambio climático, se obtuvieron cambios importantes en la distribución de las especies, y una tendencia general sur-norte. Bajo los cambios climáticos más severos, sólo los grupos que toleran las condiciones de la mayoría de las variables ambientales persisten. También se presentan estimaciones de las tasas de extinción de los taxones estudiados para los próximos 75 años. La presente metodología permite la aplicación de los indicadores ecológicos (grupos ecológicos, en este caso) para comprender las tendencias biogeográficcas.

Palabras clave: modelos de distribución de especies, variabilidad medioambiental, Maxent, conservación.

\footnotetext{
* Department of Biology, CIBIO/UP - Research Centre in Biodiversity and Genetic Resources \& Faculty of Sciences, University of Porto, Edifício FC4, Rua do Campo Alegre, S/N, 4169-007 Porto. Portugal.

** Evolution, Taxonomy and Conservation Group (ECOMED), Department of Botany, University of Salamanca, E-37008 Salamanca. Spain. Email: pacoamich@gmail.com

*** Department of Biology and Environment-CITAB, Botanical Garden and Herbarium, University of Trás-os-Montes e Alto Douro, 5001-801 Vila Real. Portugal.

**** Department of Forest and Landscape-CITAB, University of Trás-os-Montes e Alto Douro, 5001-801 Vila Real. Portugal. ***** Department of Agronomy-CITAB, University of Trás-os-Montes e Alto Douro, 5001-801 Vila Real. Portugal.
} 


\section{INTRODUCTION}

Biogeographic behaviours of several genera and species have been previously reported for the Iberian Peninsula (Olalde \& al., 2002; Petit \& al., 2002; VARGAS, 2003; MeJíAs \& al., 2007; PARDO \& al., 2008; GUZMÁN \& VARGAS, 2009; CRESPí \& al., 2007; RochA \& al., 2012a; RochA \& al., 2012b; Almeida da Silva \& al., 2014). Based on these descriptions, two distinct dynamics were identified for the western Iberian Peninsula: one along the northern mountains system, and another closer to the southern coast. Endemic and non-endemic taxa, have been used in these biogeographic descriptions. Yet, endemic taxa are much more reliable descriptors of such dynamics. In this sense, the hypothesis of centres of endemicity being areas of special evolutionary history, brings important implications for biogeographic performances (JETZ \& al., 2004). The most obvious refers to bioenvironmental restrictions, saying that endemic species with restricted distributions will also respond to limited environmental amplitudes (KRUCKEBERG \& RABINOWITZ, 1985). In this context, arises the question: could the environmental characterizations of those areas be a proper approach to explain the biogeographic dynamics at a regional scale? Accepting the hypothesis aforementioned the mapping of areas of intense evolutionary activity, can well translate endemic biogeographic trends, and can be extremely useful to describe recent floristic dynamics at a regional level (Young \& al., 2002; CALSBEEK \& al., 2003; HOPPER \& GIOIA, 2004).

The floristic distribution through the western Iberian Peninsula has been studied and analysed by several authors for different species or genera (TABerlet \& al., 1998; Hewitt, 1999; Petit \& al., 2002; PeÑuelas \& BoAda, 2003; MeJías \& al., 2007; PARDO \& al., 2008; GUZMÁN \& VARGAS, 2009; RochA \& al., 2012a). Conservational concerns (FERRIER \& al., 2002; ENGLER \& al., 2004; THUILlER \& al., 2005; RODRÍGUEZ \& al., 2007; BENITO \& al., 2009; ROCHA \& al., 2012b) and taxa sensitivity to climate change (WOHLGEMUTH 1998; GUISAN \& ThEURILlat, 2000; SANZElORZA, 2003; EliTh \& al., 2006; HARRISON \& al., 2006; BENITO GARZÓN \& al. 2007; HERNÁN-
DEZ-SANTANA \& al., 2008; RUIZ-LABOURDETTE \& $a l ., 2012)$ were the main reasons for preferentially using endemic species in these contributions.

Based on the higher sensibility of endemic taxa to environmental changes, an approach to future dynamic flows of this flora under climate change scenarios is here proposed. A set of endemic taxa with different life forms and known biogeographic distributions (and thus different sensitivities to climate change) were selected. The general requirement was their Iberian endemicity (some included taxa also occur in the south-western France and in north-western Morocco).

A Species Distribution Model (SDM) was applied to describe the spatial relationship between the species and their overall environmental variability in the geographic area (GUISAN \& THUILLER, 2005; ELITH \& LEATHWICK, 2009). After the environmental characterization of these endemisms, grouped environmentally, a forecasting analysis was developed under two predicted future scenarios of climate change, would allow a dynamic picture of these environmental groups of species to be obtained. The results achieved will be a contribution to describe the biogeographic floristic dynamics of the flora of the western Iberian Peninsula. At the same time, they will also be useful to consolidate the management conservation policies for rare or more restricted flora in western Iberian Peninsula.

\section{MATERIAL AND METHODS}

\section{STUDY AREA AND DATA COLLECTION}

The criterion used to limit the study area, was based on the general geomorphology of the Iberian Peninsula acording to RIVAS-MARTINEZ (1987) and Rivas-Martinez \& Rivas-SÁenz (2009), the Carpetan-Iberian-Leonese province has a natural border that separates the north from the south by the Central Mountains System. The southern area was defined by the Gado-Algarvian province.

The study area was refined taking in account the capacity for grouping taxa and the speciation 
described for the south-western side of the Iberian Peninsula and north-western Morocco. This effect was already pointed out by several authors for other taxa (PARDO \& al., 2008; GUZMÁN \& VARGas, 2009; Rocha \& al., 2012a; AlmeIDA DA SILVA \& al., 2014). A western biogeographic dynamics, limited by the biological Almerian and Iberian System border (HERNÁNDEZ BERMEJO \& SAÍNZ OlLERO, 1984), could explain the expansion of the floristic cast along the western part of Europe, from the Tanger-Cadiz-Algarve bay.

In order to obtain a significant resolution of the potential areas and their modelling (AUstin, 2007), it was used a species selection system that would allow to maintain the balance between the north and south quadrants, based on general and regional floras (AMARAL FRANCO, 1971, 1984; AMARAL FrANCO \& Rocha AFONSO, 1994, 1998, 2003; http://www.floraiberica.es; VALDÉs \& al., 1987; BlANCA \& al., 2011).

Although there is no clear relation between threatened species and the fact a species being endemic (according IUCN criteria, 2012), to obtain the final list of taxa included in this work, the official threatened plant lists published for the Spanish - communities of Asturias, Castilla-León, Extremadura and Andalusia (http://www.conservacionvegetal.org/legislacion.php?id_categoria=8) - were consulted. For Portugal, there is still no list of threatened species officially published (with the exception of the ones included in the Directive 92/43/CEE). Some unpublished data of field prospections, was also analysed.

With this information, 116 taxa were selected (see Table 1), based on three main criteria: a) species with a preferential distribution in the selected area; b) proportionality in the distribution along this area should be maintained (a similar number of species in its middle northern and southern part); and c) diversity of life forms.

To map their distributions occurrences were geo-referenced using a $1 \mathrm{~km}^{2}$ grid resolution (according to the pixel resolution of the environmental variables data), as recommended by GUTIÉRREZ $\&$ Pons (2006).

The locations of the species in the field, were obtained from several herbaria (67\% of the ga- thered information) possessing data form specimens of the Western Iberian Peninsula (BRESA, COI, HVR, LEB, LISE, LISI, LISU, MA, PO, SALA - http://sweetgum.nybg.org/ih/ihmapsearch.php-). Complementary information was taken from field expeditions and the Anthos database (http://www.anthos.es) for areas without other available references. The life forms classification was carried out using Raunkier's tipification, adapted from BRAUN-BLANQUET (1979).

\section{ENVIRONMENTAL CHARACTERIZATION AND POTENTIAL DISTRIBUTIONS}

Based on the occurrence of the species, an environmental assesment was made, using 68 environmental variables found in WoRLDCLIM (http: //www.worldclim.org/formats), and the thermic and pluviometric WORLDCLIM application for their analysis (http://www.worldclim.org/).

The achieved environmental matrix, in which the thermic, pluviometric and altitudinal information was specified for each location, was also applied for similar characterizations (RocHA \& al., 2012a; RochA \& al., 2012b; ALMEIDA DA SILVA \& al., 2014). A similarity analysis (Unweight Pair Group Average -UPGA- amalgamation and Manhattan City-block distances) was applied to establish environmentally similar groups. The obtained groups of species, were characterized statistically by multivariate analysis, after a previous standardization of the environmental matrix. These groups were decisive for describing the biogeographic behaviour of the selected taxa.

The most discriminating environmental variables were obtained by Discriminate Canonical Analysis (DCA), and its numerical parameters: the F statistic (F-remove) and p-levels to describe the distribution of the variable, Wilk's Lambda as the test to explain variance between variables, and tolerance (in this case, the squared multiple correlation). Finally, the representation of ranges by environmental variables and group of species, was represented by mean \pm standard deviation/mean \pm 1.96 standard deviation plots. The STATISTICA v. 9.1 software was applied for these analyses and graphic representations. 
Table 1

List of analyzed species, their general distributions in the study area (Dist: northern, N; southern, S), life forms (according to Raunkier classification), and environmental group where they were included.

\begin{tabular}{|c|c|c|c|}
\hline Species & Dist & Life forms & Environ. Group \\
\hline Aconitum napellus subsp. castellanum & $\mathrm{C}$ & Geophyte & $1 \mathrm{C}$ \\
\hline Adenocarpus argyrophyllus & $\mathrm{C}$ & Microphanerophyte & $1 \mathrm{C}$ \\
\hline Adenocarpus telonensis & $\mathrm{S}$ & Nanophanerophyte & 2 \\
\hline Allium schmitzii & NS & Helophyte & 2 \\
\hline Allium victorialis & $\mathrm{N}$ & Geophyte & $1 \mathrm{C}$ \\
\hline Anarrhinum duriminium & $\mathrm{N}$ & Chamaephyte & 2 \\
\hline Anarrhinum longipedicellatum & $\mathrm{N}$ & Hemicriptophyte & $1 \mathrm{~A}$ \\
\hline Anthemis alpestris & $\mathrm{N}$ & Chamaephyte & $1 \mathrm{C}$ \\
\hline Antirrhinum cirrhigerum & $\mathrm{S}$ & Chamaephyte & 2 \\
\hline Antirrhinum linkianum & NS & Chamaephyte & 2 \\
\hline Anthyllis vulneraria subsp. iberica & $\mathrm{N}$ & Chamaephyte & $1 \mathrm{~A}$ \\
\hline Anthyllis vulneraria subsp. sampaiana & NS & Chamaephyte & 2 \\
\hline Arabis juresii & $\mathrm{N}$ & Hemicriptophyte & $1 \mathrm{C}$ \\
\hline Arenaria querioides & $\mathrm{N}$ & Terophyte & $1 \mathrm{C}$ \\
\hline Armeria humilis subsp. humilis & $\mathrm{N}$ & Chamaephyte & $1 \mathrm{~B}$ \\
\hline Armeria humilis subsp. odorata & $\mathrm{N}$ & Chamaephyte & 1B \\
\hline Armeria linkiana & $\mathrm{S}$ & Hemicriptophyte & 20 \\
\hline Armeria velutina & $\mathrm{S}$ & Chamaephyte & 2 \\
\hline Aster aragonensis & $\mathrm{N}$ & Hemicriptophyte & $1 \mathrm{C}$ \\
\hline Bufonia macropetala & NS & Chamaephyte & $1 \mathrm{C}$ \\
\hline Calendula suffruticosa subsp. lusitanica & NS & Chamaephyte & 2 \\
\hline Calicotome villosa & $\mathrm{S}$ & Nanophanerophyte & 2 \\
\hline Carex asturica & $\mathrm{N}$ & Geophyte & 1B \\
\hline Cistus libanotis & $\mathrm{S}$ & Nanophanerophyte & 2 \\
\hline Cytisus arboreus subsp. baeticus & $\mathrm{S}$ & Microphanerophyte & 2 \\
\hline Cytisus grandiflorus subsp. cabezudoi & $\mathrm{S}$ & Nanophanerophyte & 2 \\
\hline Dianthus langeanus & $\mathrm{N}$ & Chamaephyte & $1 \mathrm{C}$ \\
\hline Digitalis purpurea subsp. amandiana & $\mathrm{N}$ & Hemicryptophyte & 2 \\
\hline Diplotaxis siifolia subsp. vicentina & $\mathrm{S}$ & Terophyte & 2 \\
\hline Drosophyllum lusitanicum & NS & Geophyte & 2 \\
\hline Echinospartum ibericum & $\mathrm{N}$ & Nanophanerophyte & $1 \mathrm{C}$ \\
\hline Elaeoselinum foetidum & $\mathrm{S}$ & Hemicryptophyte & 2 \\
\hline Erica lusitanica & NS & Nanophanerophyte & 2 \\
\hline Erophaca baetica & NS & Hemicryptophyte & 2 \\
\hline Erysimum merxmuelleri & $\mathrm{S}$ & Chamaephyte & $1 \mathrm{C}$ \\
\hline Euphorbia polygalifolia subsp. polygalifolia & $\mathrm{N}$ & Chamaephyte & $1 \mathrm{C}$ \\
\hline Euphorbia uliginosa & $\mathrm{N}$ & Chamaephyte & 2 \\
\hline Festuca duriotagana & NS & Hemicryptophyte & 2 \\
\hline Festuca summilusitana & $\mathrm{N}$ & Hemicriptophyte & $1 \mathrm{~B}$ \\
\hline Galega cirujanoi & $\mathrm{C}$ & Hemicriptophyte & 2 \\
\hline Galium glaucum subsp. australis & $\mathrm{N}$ & Hemicriptophyte & 2 \\
\hline Genista ancistrocarpa & $\mathrm{N}$ & Nanophanerophyte & 2 \\
\hline Genista berberidea & $\mathrm{N}$ & Nanophanerophyte & $1 \mathrm{~A}$ \\
\hline Genista carpetana & $\mathrm{N}$ & Chamaephyte & $1 \mathrm{C}$ \\
\hline Genista hystrix & $\mathrm{N}$ & Nanophanerophyte & $1 \mathrm{C}$ \\
\hline Genista micrantha & $\mathrm{N}$ & Chamaephyte & $1 \mathrm{C}$ \\
\hline Genista polyanthos & $\mathrm{S}$ & Nanophanerophyte & 2 \\
\hline Genista sanabrensis & $\mathrm{N}$ & Nanophanerophyte & 3 \\
\hline Genista tournefortii & NS & Chamaephyte & $1 \mathrm{C}$ \\
\hline Genista triacanthos & NS & Nanophanerophyte & 2 \\
\hline
\end{tabular}




\begin{tabular}{|c|c|c|c|}
\hline Species & Dist & Life forms & Environ. Group \\
\hline Halimium calycinum & $\mathrm{S}$ & Chamaephyte & 2 \\
\hline Halimium umbellatum subsp. umbellatum & $\mathrm{N}$ & Chamaephyte & $1 \mathrm{C}$ \\
\hline Holcus annus subsp. duriensis & $\mathrm{N}$ & Terophyte & 2 \\
\hline Holcus gayanus & $\mathrm{N}$ & Terophyte & $1 \mathrm{C}$ \\
\hline Hyacinthoides mauritanica & $\mathrm{S}$ & Geophyte & 2 \\
\hline Hymenostemma pseudanthemis & $\mathrm{S}$ & Terophyte & 2 \\
\hline Iberis procumbens subsp. procumbens & $\mathrm{S}$ & Chamaephyte & 2 \\
\hline Jasione cavanillesii & $\mathrm{N}$ & Chamaephyte & 3 \\
\hline Jasione crispa subsp. mariana & $\mathrm{C}$ & Chamaephyte & 2 \\
\hline Juncus emmanuelis & $\mathrm{S}$ & Helophyte & 2 \\
\hline Lavandula viridis & $\mathrm{S}$ & Chamaephyte & 2 \\
\hline Limonium algarvense & $\mathrm{S}$ & Hemicryptophyte & 2 \\
\hline Limonium ovalifolium & $\mathrm{S}$ & Chamaephyte & 2 \\
\hline Loeflingia baetica & $\mathrm{S}$ & Terophyte & 2 \\
\hline Malva hispanica & $\mathrm{S}$ & Chamaephyte & 2 \\
\hline Marsilea batardae & $\mathrm{S}$ & Helophyte & 2 \\
\hline Mercurialis reverchonii & $\mathrm{S}$ & Chamaephyte & 2 \\
\hline Narcissus asturiensis & $\mathrm{N}$ & Geophyte & $1 \mathrm{~B}$ \\
\hline Nothobartsia asperrima & NS & Chamaephyte & 2 \\
\hline Ononis broteriana & NS & Terophyte & 2 \\
\hline Ononis cintrana & $\mathrm{S}$ & Terophyte & 2 \\
\hline Otospermum glabrum & $\mathrm{S}$ & Terophyte & 2 \\
\hline Paradisea lusitanica & $\mathrm{N}$ & Geophyte & $1 \mathrm{C}$ \\
\hline Pistorinia hispanica & NS & Terophyte & $1 \mathrm{C}$ \\
\hline Plantago monosperma subsp. discolor & $\mathrm{N}$ & Chamaephyte & $1 \mathrm{C}$ \\
\hline Polygala baetica & $\mathrm{S}$ & Chamaephyte & 2 \\
\hline Rhododendrum ponticum subsp. baeticum & NS & Microphanerophyte & 2 \\
\hline Rhynchospora modesti-lucennoi & $S$ & Chamaephyte & 2 \\
\hline Santolina semidentata & $\mathrm{N}$ & Chamaephyte & $1 \mathrm{C}$ \\
\hline Scrophularia sambucifolia & $\mathrm{S}$ & Hemicriptophyte & 2 \\
\hline Scrophularia sublyrata & NS & Hemicriptophyte & 2 \\
\hline Selinum broteri & $\mathrm{N}$ & Hemicriptophyte & $1 \mathrm{C}$ \\
\hline Sempervivum vicentei & $\mathrm{N}$ & Chamaephyte & 3 \\
\hline Sideritis arborescens & $\mathrm{S}$ & Chamaephyte & 2 \\
\hline Sideritis lurida & NS & Chamaephyte & $1 \mathrm{C}$ \\
\hline Silene acutifolia & $\mathrm{N}$ & Hemicriptophyte & 1B \\
\hline Silene coutinhoi & $\mathrm{N}$ & Hemicriptophyte & 2 \\
\hline Silene longicilia & NS & Hemicriptophyte & 2 \\
\hline Silene mariana & $\mathrm{S}$ & Terophyte & 2 \\
\hline Silene marizii & $\mathrm{N}$ & Hemicriptophyte & $1 \mathrm{C}$ \\
\hline Spergula viscosa & $\mathrm{N}$ & Chamaephyte & 3 \\
\hline Stauracanthus genistoides & $\mathrm{S}$ & Nanophanerophyte & 2 \\
\hline Succisella microcephala & $\mathrm{C}$ & Chamaephyte & $1 \mathrm{C}$ \\
\hline Teucrium algarbiense & $\mathrm{S}$ & Chamaephyte & 2 \\
\hline Teucrium salviastrum & $\mathrm{N}$ & Chamaephyte & $1 \mathrm{~B}$ \\
\hline Thapsia minor & NS & Hemicriptophyte & 2 \\
\hline Thapsia nitida & $\mathrm{S}$ & Hemicriptophyte & 2 \\
\hline Thapsia transtagana & $\mathrm{S}$ & Hemicriptophyte & 2 \\
\hline Thymelaea broteriana & $\mathrm{N}$ & Chamaephyte & $1 \mathrm{C}$ \\
\hline Thymelaea lanuginosa & $\mathrm{S}$ & Nanophanerophyte & 2 \\
\hline Thymus albicans & $\mathrm{S}$ & Chamaephyte & 2 \\
\hline Thymus carnosus & $\mathrm{S}$ & Chamaephyte & 2 \\
\hline Thymus villosus subsp. lusitanicus & $\mathrm{S}$ & Chamaephyte & 2 \\
\hline Thymus zygis subsp. sylvestris & $\mathrm{S}$ & Chamaephyte & 2 \\
\hline
\end{tabular}




\begin{tabular}{llll} 
Species & Dist & Life forms & Environ. Group \\
\hline Thymus villosus subsp. villosus & $\mathrm{S}$ & Chamaephyte & 2 \\
Thymus zygis subsp. zygis & $\mathrm{N}$ & Chamaephyte & $1 \mathrm{C}$ \\
Ulex argenteus & $\mathrm{S}$ & Nanophanerophyte & 2 \\
Ulex erinacenus & $\mathrm{S}$ & Chamaephyte & 2 \\
Ulex micranthus & $\mathrm{N}$ & Nanophanerophyte & $1 \mathrm{~A}$ \\
Verbascum barnadesii & $\mathrm{S}$ & Hemicriptophyte & 2 \\
Verbascum litigiosum & $\mathrm{S}$ & Hemicriptophyte & 2 \\
Verbascum giganteum subsp. martinezii & $\mathrm{S}$ & Hemicriptophyte & 2 \\
Veronica mampodrensis & $\mathrm{N}$ & Chamaephyte & 3 \\
Veronica micrantha & $\mathrm{N}$ & Chamaephyte & $1 \mathrm{C}$ \\
Viola langeana & $\mathrm{N}$ & Hemicriptophyte & $1 \mathrm{C}$ \\
Xolantha globulariifolia & $\mathrm{N}$ & Hemicriptophyte & $1 \mathrm{C}$
\end{tabular}

The potential habitat distribution areas and previsions for environmental groups and subgroups, were obtained with the MAXENT software, v. 3.3.3e (http://www.cs.princeton.edu/ schapire/maxent/). MAXENT estimates the distribution probability of a species occurrence, based on environmental constraints (PHILLIPS \& al., 2006). It only requires the data of the species presence, and the environmental variables in GIS layers, for the study area. The MAXENT software was used to estimate the probability of a potentially suitable habitat for species occurrence, varying from 0 to 1 , where 0 is the lowest and 1 the highest probability.

The modelling approach was validated based on the probability that locations with a confirmed presence of the species, ranked higher than a random background probability, also with a characteristic receiver-operating (ROC) plot (FIELDING $\&$ BeLL 1997), and an area under the curve (AUC) approach (PHILLIPS \& al. 2006). Locations with a random background probability served as pseudo-absences for all analyses in MAXENT (PHILLIPS \& al., 2004; PHILLIPS \& al., 2006).

The MAXENT jack-knife approach was used for assessing the importance of the variable (YosT \& al., 2008). The training gain was calculated for each variable as well as the drop in training gain when the variable was omitted from the full model (PHILLIPS \& al., 2006).

For all models, the following parameters were used: 10 repetitions with cross-validation, standard regularization multiplier (affects how focused or closely-fitted the output distribution is), 500 iterations (for further details on these para- meters, see PHILLIPS (2010) and a threeshold of 0.5 , meaning that only suitable habitat areas ranking higher than 0.5 of probability of occurrence were chosen - to describe the most significant distribution areas. The output obtained (in ASCII format) was then used as input for a GIS project (ArcGIS software version 9.2 - ESRI, Redlands, California, USA) as a floating-point grid (PETERSON \& al. 2007), revealing the probability of the occurrence of the species at each site and resulting in a continuous map.

\section{MODELLING THE POTENTIAL FUTURE DISTRIBUTIONS}

The climate predictors were derived from a general circulation model (CCCMA: CGCM2) for 2080, under the IPCC emission scenarios (SRES; $\mathrm{A} 2 \mathrm{a}$ and $\mathrm{B} 2 \mathrm{a}$ ) for predicting future potential distribution areas (http://gisweb.ciat.cgiar.org/GCMPage; RAMíREZ \& JARVIS, 2008). The scenarios A2a and B2a represent two different possible situations of greenhouse gas emissions. In comparison with A2a, B2a has a lower rate of global warming, and hence changes in temperature and precipitation are less intense (http://forest.jrc.ec.europa.eu/climate-change/future-trends).

In order to confirm the previsions per environmental group, potential distribution areas and previsions for both future scenarios were also elaborated for each species individually. This approach was necessary to confirm the result obtained for every environmental group, based on the variability of information included in each group. 


\section{RESULTS}

\section{ENVIRONMENTAL CHARACTERIZATION AND POTENTIAL DISTRIBUTIONS}

The map detailing the present known distribution of taxa is shown in Figure 1 (for 2983 confirmed locations). A total $40 \%$ of the studied species were concentrated in the north, $40 \%$ in the south, $4 \%$ just in the center, and the remaining $16 \%$ along the area.

The similarity analysis on the environmental matrix is shown in the dendrogram of Figure 2a. Three basic groups were primarily observed: groups 1,2 and 3 . The first one is subdivided in three subgroups: group 1a, 1b, and 1c. This classification is deduced according to the CDA for the environmental matrix, for the most discriminant classification (the highest F, highest Wilks' lambda, and lowest pvalue) deduced from the dendrogram obtained from the similarity analysis. The CDA for the environmental matrix classified into five environmental groups (included here the three subdivisions of group 1) is graphically represented in Figure 2b. Altitude $(\mathrm{F}=11.857$, $\mathrm{p}$-level<0.001) and precipitation seasonality (bio $05, \mathrm{~F}=10.350$, p-level $<0.001$ ) are the most discriminant environmental variables to distinguish those five groups (Table 2). This last environmental variable describes the variability of average precipitation among seasons along the year (coefficient of variation between seasons).

The potential distribution map for the environmental groups is exposed in Figure 3. The concentration of habitats suitable for harbouring the environmental groups is clearly different for group 1 and 2, but regionally overlapped in the north-eastern. The potential environmental distribution for group 1 (subgroups $1 \mathrm{a}, 1 \mathrm{~b}$ and $1 \mathrm{c}$ ) is concentrated in the northern of the area, for group 2 is extended along the whole area (at low altitude). The potential occurrence of group 3 is also located in the northern area, but at the highest altitudes of the Cantabrian mountain system.

In the case of group 1, the three potential distributions of subgroups $1 \mathrm{a}, 1 \mathrm{~b}$ and $1 \mathrm{c}$ are evidently distinguished. Potential occurrence for subgroup 1a is along the coast and at low altitudes of north-western and north; subgroup $1 \mathrm{~b}$ is restricted to the occident of the lusitanian-gallaecian mountain system; and subgroup $1 \mathrm{c}$ is more concentrated in the most continental side of the north-western and northern of the area.

The life form description of each environmental group and subgroup is exposed in Table 3 . In

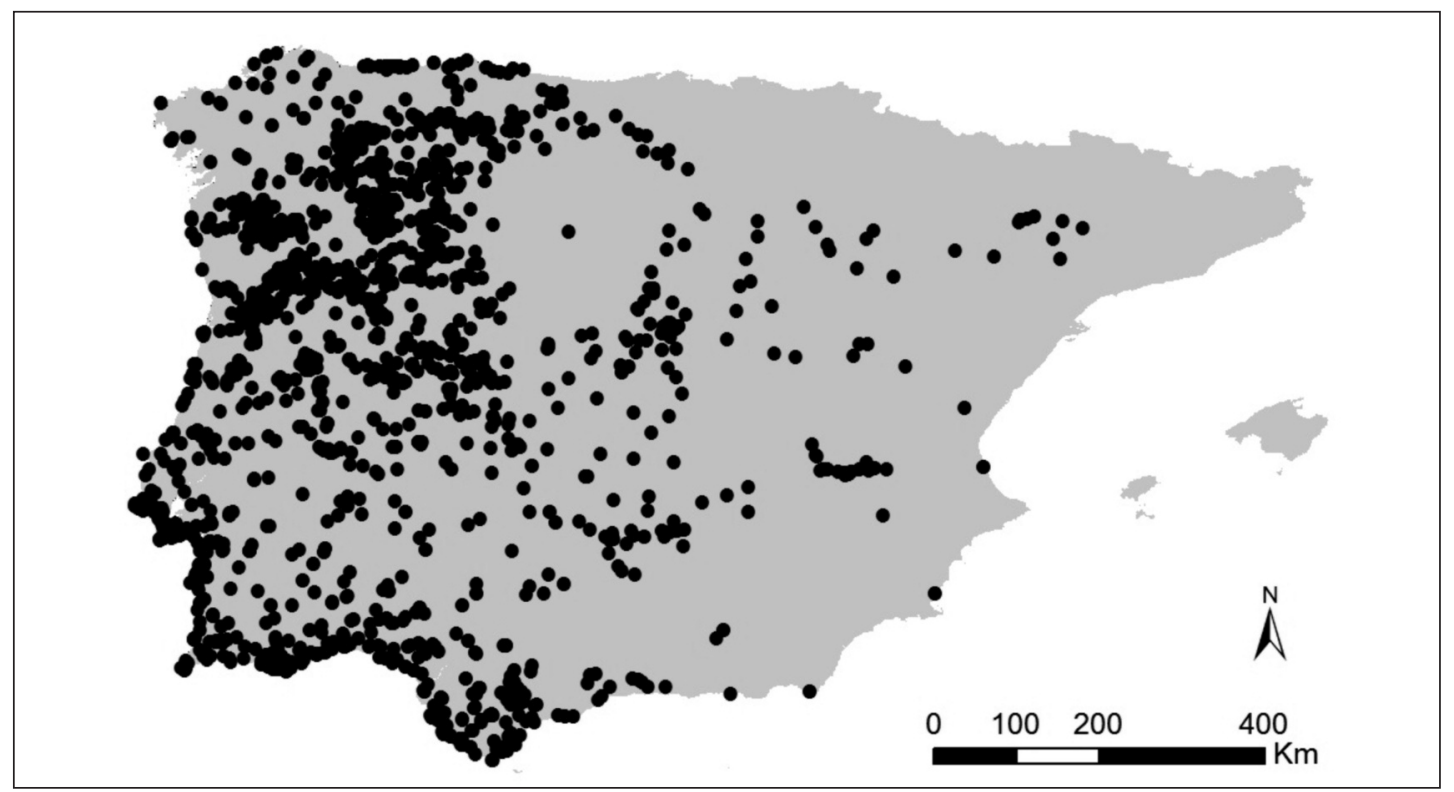

Figure 1. - Distribution maps of populations occurrences for all the species analysed. 
a

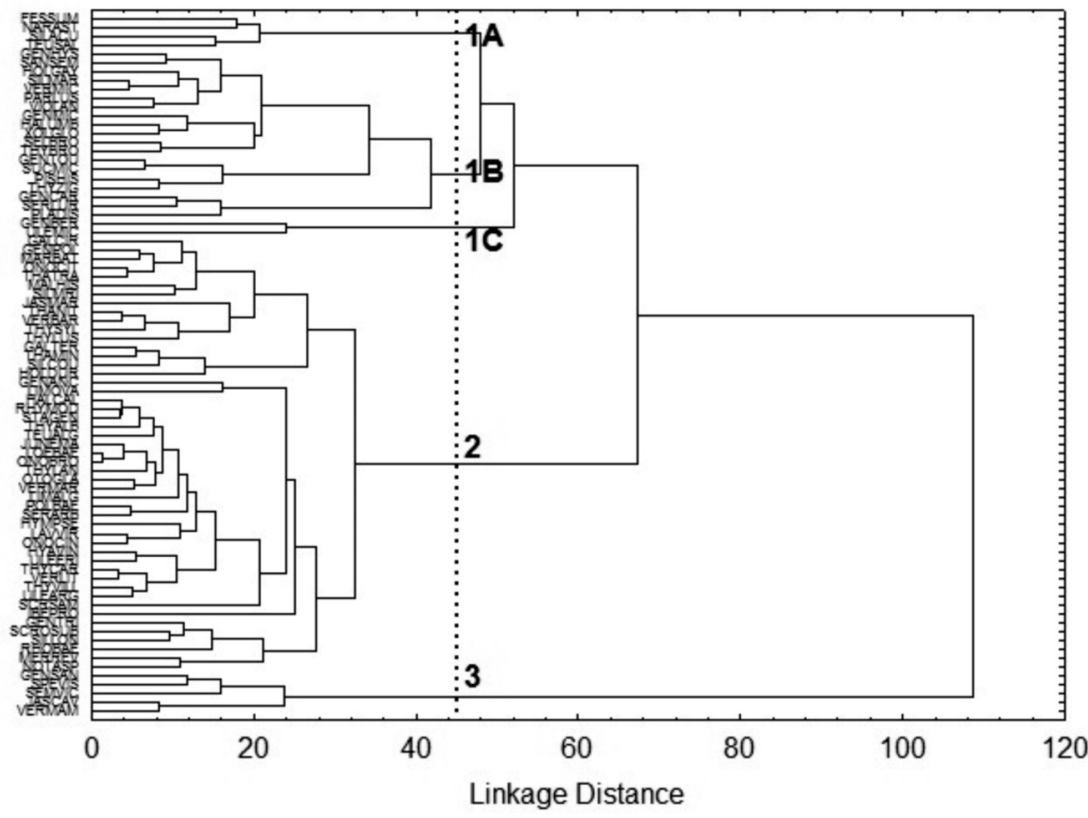

$\triangle \operatorname{Gr} 1 A ; \circ$ Gr $1 B ; *$ Gr $1 C ; \Delta$ Gr $3 ; \bullet$ Gr 2

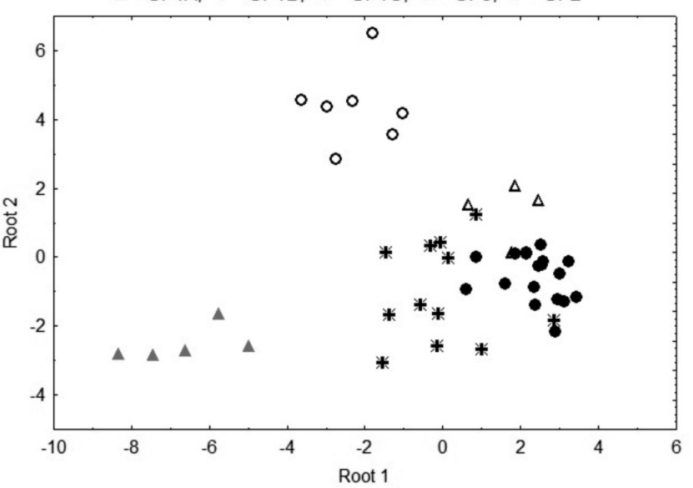

Figure 2.- Multivariate analysis of the environmental matrix: (a) dendrogram obtained from the similarity analysis of average environmental variables per taxon, with groups (Gr.) and subgroups (Sgr.) represented, and their maps of current potential distribution; (b) graphic representation of DCA for the five groups (1-1a, 1b, and 1c-, 2 and 3).

Table 2

Numerical values of CDA for the environmental matrix. Altitude $(\mathrm{F}=11.857$, p-level<0.001) and precipitation seasonality (bio 5, $\mathrm{F}=10.350$, p-level $<0.001$ ) are the most discriminant environmental variables.

\begin{tabular}{lcccc}
\hline & Wilks' Lambda & $\begin{array}{c}\text { F-remove } \\
(4,51)\end{array}$ & p-level & Toler. \\
\hline altitude & 0,030243 & 10,21554 & 0,000004 & 0,409161 \\
prec4 & 0,026711 & 7,53363 & 0,000076 & 0,099515 \\
prec1 & 0,028414 & 8,82649 & 0,000017 & 0,066694 \\
bio 5 & 0,030666 & 10,53671 & 0,000003 & 0,159397 \\
tmin7 & 0,024746 & 6,04113 & 0,000466 & 0,186567 \\
\hline
\end{tabular}



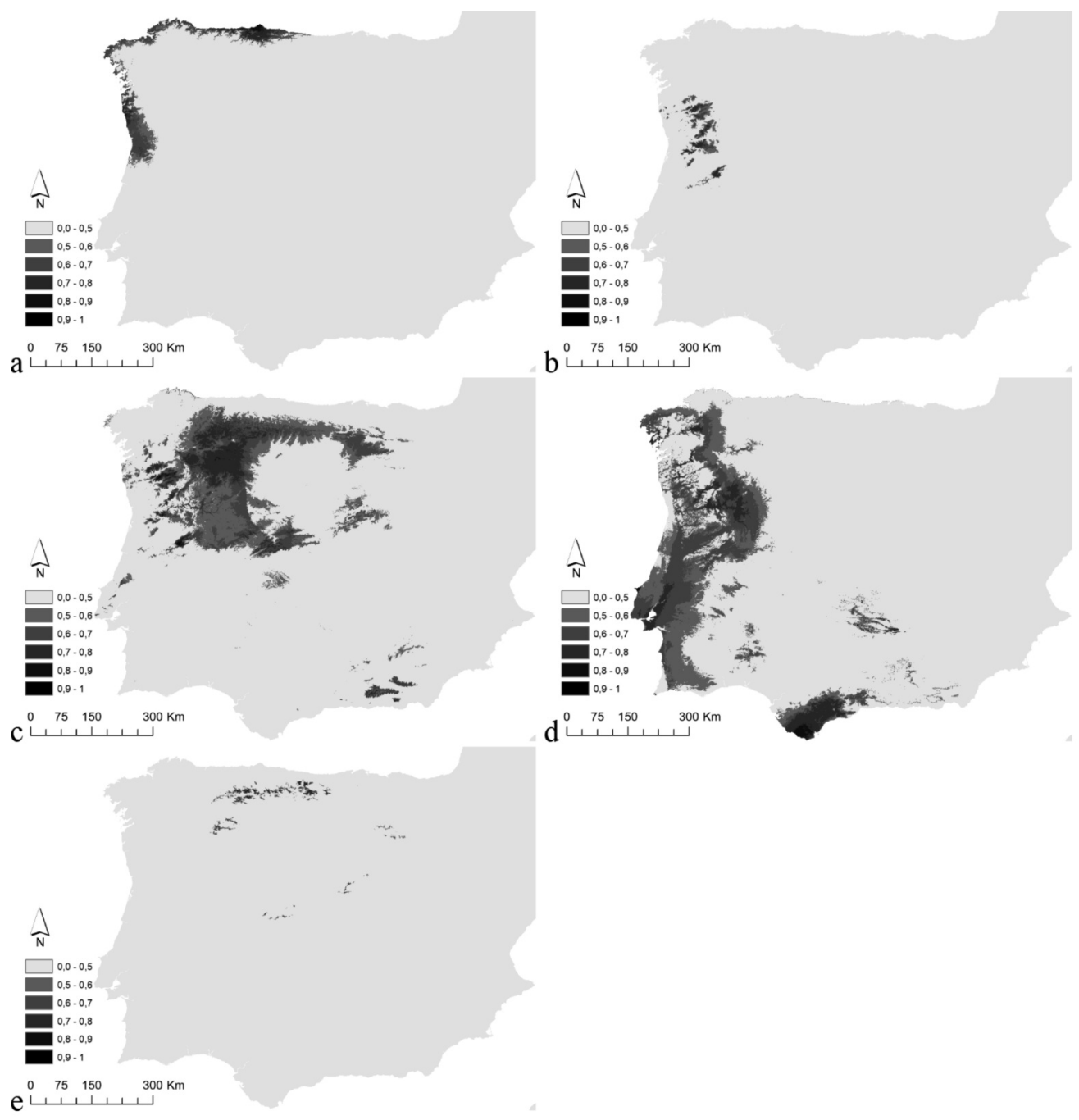

Figure 3. - Potential distribution areas for the bioclimatic groups: a) group 1a, b) group 1b, c) group 1c, d) group 2, and e) group 3. All these bioclimatic groups are represented for the middle northern of the study area, in contrast with the middle southern where just group 2 occurs.

terms of life forms, $9 \%$ were therophytes, $23 \%$ hemicryptophytes, $6 \%$ geophytes, $42 \%$ chamaephytes, $14 \%$ nanophanerophytes, $3 \%$ microphanerophytes, and 3\% helophytes.

Group 2 and subgroup 1c are the most diverse in terms of life forms. In contrast, the rest of the environmental groups are extremely restricted: biannual (hemicriptophytes) or perennial herbaceous (geophytes and chamaephytes), or small shrubs (nanophanerophytes) are the only forms observed. These results could be associated with the environmental variability obtained for groups 2 and $1 \mathrm{c}$, both of them very similar about their altitudinal ranges (Figure 4).

\section{MODELLING THE POTENTIAL FUTURE DISTRIBUTIONS}

Projections of potential distributions for environmental groups 2, for both 2080 scenarios, show an evident shift towards the northern part of the Iberian Peninsula (Figure 5). Groups 3 and 
Table 3

Percentages of life forms per environmental group (Tero, terophytes; Hemi, hemicriptophyte; Geop, geophytes; Helo, helophytes; Cham, chamaephytes; Nano, nanopharerophytes; Micr, microphanerophytes).

\begin{tabular}{llllllll}
\hline & Tero & Hemi & Geop & Helo & Cham & Nano & Micr \\
Group 1a & 0 & 3,7 & 0 & 0 & 2,04 & 12,5 & 0 \\
Group 1b & 0 & 7,41 & 28,57 & 0 & 6,12 & 0 & 0 \\
Group 1c & 27,27 & 22,22 & 42,86 & 0 & 32,65 & 12,5 & 33,33 \\
Group 2 & 72,73 & 66,67 & 28,57 & 100 & 51,02 & 68,75 & 66,67 \\
Group 3 & 0 & 0 & 0 & 0 & 8,16 & 6,25 & 0 \\
\hline
\end{tabular}

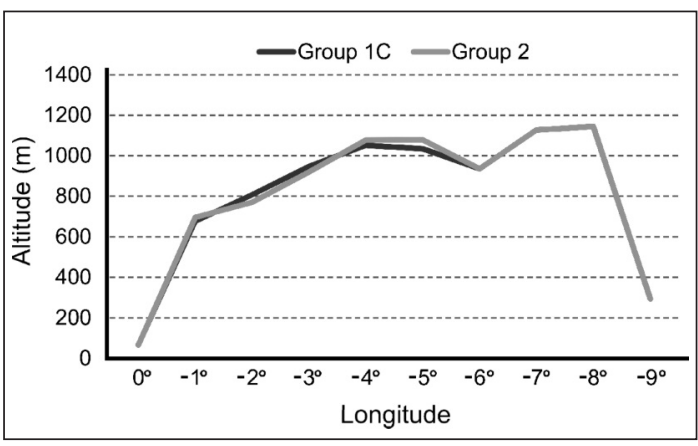

Figure 4. - Average altitude for the $1 \mathrm{c}$ and 2 bioclimatic groups from eastern to western of the study area. Both bioclimatic groups show a very similar and wide altitudinal range.
1 , with subgroups $1 \mathrm{a}, 1 \mathrm{~b}$, and $1 \mathrm{c}$, reflect significant decreases or even extinctions (group 3 for both scenarios, and subgroup $1 \mathrm{~b}$ for the A2a scenario) in the potential habitat distributions.

The current thermic and pluviometric characterization per envionmental group is explained in Table 4. Group 3 and subgroups $1 \mathrm{a}$ and $1 \mathrm{c}$ are clearly cooler than group 2 or subgroup $1 \mathrm{~b}$. This circumstance is maintained for the future climatic change scenarios $\mathrm{A} 2 \mathrm{a}$ and $\mathrm{B} 2 \mathrm{a}$, where an increasing of $3^{\circ}-4^{\circ} \mathrm{C}$ and a decreasing in $20 \%$ for annual precipitation are confirmed for all the environmental groups. These results are in accordance with previous previsions for Mediterranean areas (LOARIE \& al., 2009).

Table 4

Thermic and pluviometric values for the current situation and for the climate scenarios analysed (A2a and B2a) in 2080, based on the annual average precipitation (P), annual lowest temperature (tmin) and annual highest temperature (tmax), per environmental group.

\begin{tabular}{|c|c|c|c|c|c|c|c|c|c|}
\hline Groups & $\begin{array}{l}\text { Current } \\
\mathrm{P}(\mathrm{mm})\end{array}$ & $\operatorname{tmin}\left({ }^{\circ} \mathrm{C}\right)$ & $\operatorname{tmax}\left({ }^{\circ} \mathrm{C}\right)$ & $\begin{array}{l}2080 \mathrm{~A} 2 \mathrm{a} \\
\mathrm{P}(\mathrm{mm})\end{array}$ & $\operatorname{tmin}\left({ }^{\circ} \mathrm{C}\right)$ & $\operatorname{tmax}\left({ }^{\circ} \mathrm{C}\right)$ & $\begin{array}{l}2080 \mathrm{~B} 2 \mathrm{a} \\
\mathrm{P}(\mathrm{mm})\end{array}$ & $\operatorname{tmin}\left({ }^{\circ} \mathrm{C}\right)$ & $\operatorname{tmax}\left({ }^{\circ} \mathrm{C}\right)$ \\
\hline $1 \mathrm{a}$ & 87 & 1 & 11 & 69 & 4 & 15 & 80 & 3 & 14 \\
\hline $1 b$ & 88 & 10 & 18 & 73 & 12 & 21 & 83 & 12 & 20 \\
\hline $1 \mathrm{c}$ & 120 & 6 & 15 & 98 & 9 & 18 & 113 & 8 & 17 \\
\hline 3 & 70 & 6 & 16 & 56 & 9 & 20 & 65 & 8 & 19 \\
\hline 2 & 55 & 11 & 21 & 43 & 14 & 24 & 49 & 13 & 23 \\
\hline
\end{tabular}

Table 5

Potential areas of the bioclimatic groups $\left(\mathrm{Km}^{2}\right)$, under the current climatic conditions and for both future climate scenarios (A2 and B2). Surfaces were also calculated based on the species distributions of each group (with $*$ ).

\begin{tabular}{|c|c|c|c|c|c|}
\hline & Group 1a & Group 1b & Group 1c & Group 2 & Group 3 \\
\hline Current & 20495 & 7234 & 116460 & 139247 & 4251 \\
\hline $2080 \mathrm{~A} 2 \mathrm{a}$ & 2031 & 0 & 9021 & 72502 & 0 \\
\hline $2080 \mathrm{~B} 2 \mathrm{a}$ & 16050 & 703 & 50087 & 91485 & 62 \\
\hline 2080 A2a* & 595 & 1321 & 72291 & 76996 & 0 \\
\hline 2080 B $2 a^{*}$ & 5245 & 4624 & 86972 & 69256 & 517 \\
\hline
\end{tabular}


The surfaces occupied by the groups in the future scenarios are also very explicit (Table 5). Group 3 and subgroup $1 \mathrm{~b}$ will disappear (A2a) or reduce severally their surfaces (B2a). For the other groups substantial decreases are verified. The largest group (group 2) is the most resistant, keeping extensive areas in both scenarios.

The individual analysis of every species (for the current climatic conditions and for the future scenarios) is also exposed in Table 5. With the exception of groups $1 \mathrm{c}$ and 2 -where the areas previewed in both scenarios are much higher than those previewed as a group (subgroup 1c), or with opposite results (group 2)-, the other environmental groups show similar behaviors. The cases of groups $1 \mathrm{c}$ and 2 could be explained by their environmental variability. In fact, the potential areas deduced for both, are significantly higher than for the others ( $1 \mathrm{a}, 1 \mathrm{~b}$ and 3$)$. This issue will force the subdivision of groups 1c and 2, in order to obtain a better description for future scenarios.

The significance of the changes observed for the potential distribution per environmental group and subgroup, in both climate change scenarios, analysed by a CDA (Figure 6a-c), shows that the highest average temperature in July (tmax7) exposes the most important variations between the current and the future conditions. These variations are more relevant for the group 3 and the subgroups 1, than for the group 2.

\section{DISCUSSION}

Several authors have discussed an expected northward displacement of the flora in result of future climate changes (HuNTLEY \& al., 1995; COMES \& Kadereit, 1998; PUIG DE FÁBREgas \& MendizABAL, 1998; Walther, 2003; Jump \& al., 2006a, b; BENITO GARZÓn \& al., 2008; RodRíGUEZ SÁNCHEZ \& ARROYO, 2008; RochA \& al., $2012 b)$. Several modelling approaches have been elaborated, with different ecological and geographic ranges for species (GUISAN \& THEURILLAT, 2000; al. \& al., 2003; ENGLER \& al., 2004; RANDIN \& al., 2006; RUIZ-LABOURDETTE \& al., 2012). Yet, all the mentioned cases, the modelling was applied individually by taxon, and not to sets of taxa. However, contributions using groups of species with similar ecological amplitudes (TERBRAAK \& GREMMEN, 1987) or sets of endemic species with different life forms (BROENNIMANN \& al., 2006), have reported promising results.

Three different types of behaviours were found: two of them are represented by potential distributions on the northern (groups 1 and 3), and one along the analysed area (group 2). In group 1 , three behaviours are distinguished for the northern potential habitats of the group 1 , one of them is restricted to potential habitats along the coast (subgroup 1a), a second one for the most occidental mountains (subgroup 1b), and the third group describes dryer and continental potential habitats (subgroup 1c).

Traditionally, the areas where the studied species are concentrated (both in the north and in the southern biogeographic area) have been referred as biological refugia (MÉDAIL \& QuEZEL, 1997; Moreno Saíz \& Saínz Ollero, 1997; Moreno SAíz \& al., 1998; LoBo \& al., 2001; GiMÉNEZ \& al., 2004).

These results help to understand the gene flow proposed by several authors for the western Iberian Peninsula (TABERLET \& al., 1998; Olalde \& al., 2002; Petit \& al., 2002; VARGas, 2003; MeJías \& al., 2007; PARDO \& al., 2008; GUZMÁN \& VARGAS, 2009; ROCHA \& al., 2012a), and to explain the significant geographic environmental connectivity along the western of the Iberian Peninsula (group 2 and subgroup 1c). The high concentration of endemic species in northwestern Iberian Peninsula is explained by the presence of distinct potential habitats for mountains (group 3 and subgroup 1b) and north coast (subgroup 1a). On the contrary the high environmental variability for groups $1 \mathrm{c}$ and 2 with significant divergences between grouping and specific predictions will demand more subdivisons. Additionally, the rapid response of all the environmental groups to climate changes indicates an extremely thermic and pluviometric dynamic. This rapid response could reflect a very active gene flow, possibly as a result of the characteristic intense climatic variability prevailing since the late Pliocene (OLDFIELD, 2005; TZEDAKIS, 2007). These relevant changes have 

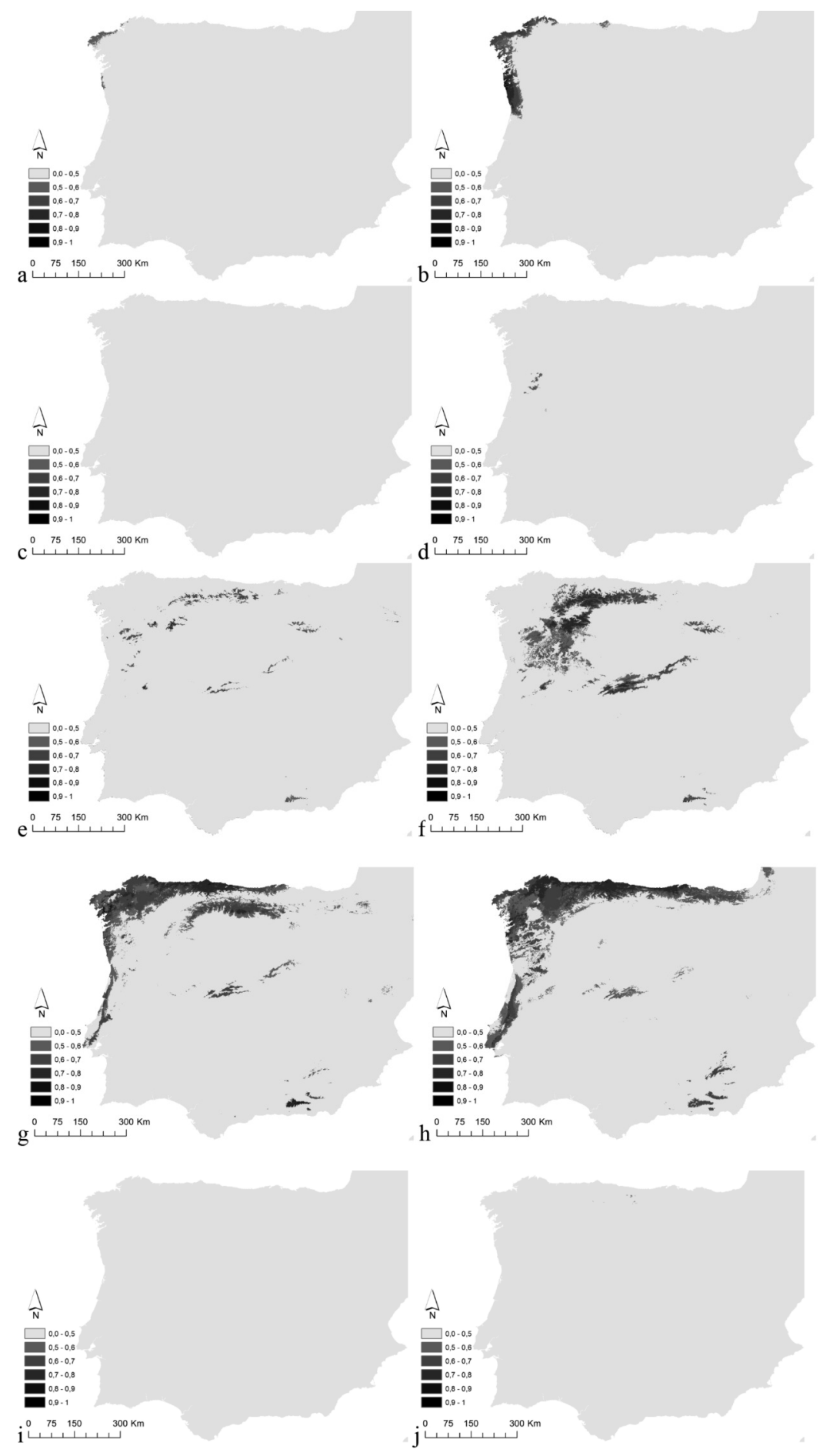

Figure 5. - Bioclimatic groups areas under the effect of future climate change scenarios A2 and B2 in 2080: a) group $1 \mathrm{~A}$ for A2 scenario; b) group $1 \mathrm{a}$ for $\mathrm{B} 2$ scenario; c) group $1 \mathrm{~b}$ for A2 scenario; d) group $1 \mathrm{~b}$ for B2 scenario; e) group $1 \mathrm{c}$ for A2 scenario; f) group 1c for B2 scenario; g) group 2 for A2 scenario; h) group 2 for B2 scenario; i) group 3 for A2 scenario; j) group 3 for $\mathrm{B} 2$ scenario. 

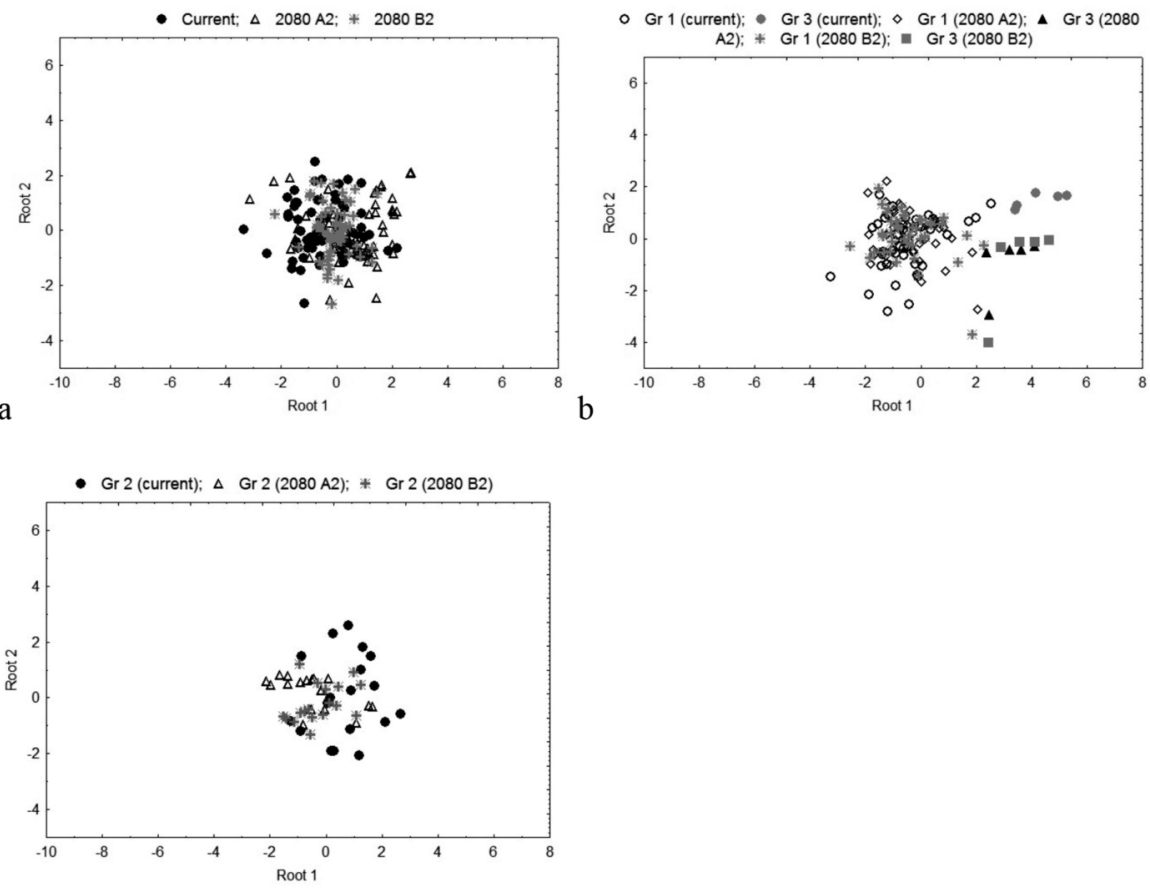

c

Figure 6. - CDA graphic representation for the first two roots, a) for current and future climate change scenarios for the five bioclimatic groups; b) for group 1 (1a, 1b and 1c) and group 3; and c) for group 2 .

determined the migration of individuals across western Europe (HEWITT, 1996; TABERLET \& al., 1998). Advances and setbacks, the access to different altitudinal levels, and the contact between different types of biogeographic behavior have been the main consequences of this intensive biogeographic dynamic (GUTIÉRREZ LARENA \& al., 2002; HeWITT, 2004; FRAJMAN \& OXELMAN, 2007; MÉdail \& Diadema, 2009). In this sense, the peninsular geomorphological variability has acted as an extremely important distributing regulator in this biological process (SWANSON \& al., 1988; STALLINS, 2006). This dynamic biological and environmental correlation is now involved in the refugee discussion (MÉDAIL \& Diadema, 2009; Gómez \& Lunt, 2007; Nieto FELINER, 2011, 2014). The lack of thermic and pluviometric stability introduces the possibility of dynamic refugia, in contrast with the static idea of environmental areas where species will find their potential habitat. In accordance with this discussion, the endemic species especially those with more restricted ecological amplitudes, will be biological indicators of this process.

The results obtained for future climatic change scenarios show alarming thermic and pluviometric forecasts for the preservation of species. Special attention must be considered for the mountain groups (group 3 and subgroup 1b), and north Atlantic potential habitats, seriously threaten. Results such as those discussed here draw attention to the importance of monitoring policies, to guarantee the preservation of the species with occurrence in the most sensitive environmental groups and subgroups.

In the present work the groups, obtained by similarity of thermic, pluviometric and altitudinal amplitudes of endemic and restricted subendemic species contribute to describe the biogeographic floristic dynamics of the flora of the western Iberian Peninsula. To know the geographic dynamic of these environmental groups under future climate changes, will also be very useful for conservation purposes, or even to understand and 
explain quaternary phylogenetic routes (COMES \& KADEREIT, 1998; TABERLET \& al., 1998; OLALDE \& al., 2002; VARGAS, 2003).

\section{CONCLUSIONS}

The diversity of environmental groups and subgroups, which are significantly different on the western Iberian Peninsula, reflects the potential habitat complexity of this region. Anyway, the continuity along these environmental clusters of potential habitats along the study area is guaranteed by the groups and subgroups detected. In this sense, restricted and broader environmental amplitudes are obtained for these environmental subgroups.

A very dynamic biogeographic behavior is deduced by these environmental groups and subgroups when exposed to future climate changes scenarios. A trend to north of the area, as well as important transformations in the potential habitat areas and the elimination of some of them, are the most relevant consequences of this forecast. These results allowed to understand the recent gene flow across this area described by several authors, but at the same time the environmental groups here described seem useful biological indicators for recent biogeographic trends in western Iberian Peninsula.

\section{ACKNOWLEDGEMENTS}

João Rocha thanks FCT for a grant (SFRH/ BD/43167/ 2008). The authors would like to express their gratitude to Professor João Honrado (Department of Biology, Faculty of Sciences, University of Porto) for his important contribution. They also want to thank to two anonymous reviewers for the comments made to the manuscript.

\section{REFERENCES}

Amaral Franco, J. - 1971, 84- Nova flora de Portugal (continente e Açores), vols. 1, 2 - Ed. J.A. Franco, Lisboa.

Amaral Franco, J. \& Rocha Afonso, M.L. - 1994, 98, $2003-$ Nova Flora de Portugal vol. 3 - Escolar Ed., Lisboa.

Austin, M. -2007- . Species distribution models and ecological theory: a critical assessment and some possible new approaches - Ecol. Model. 200: 1-19.

Benito, B., Martínez-Ortega, M.M., Muñoz, L.M., Lorite, J. \& Peñas, J. -2009- Assessing extinction-risk of endangered plants using species distribution models: a case study of habitat depletion caused by the spread of greenhouses - Biodiv. Cons. 18: 2509-2520.

Benito Garzón, M., Sánchez de Dios, R. \& Sáinz Ollero, H. -2007- Predictive modeling of tree species distributions on the Iberian Peninsula during the Last Glacial Maximum mid-Holocene - Ecography 30: 120-134.

Benito Garzón, M., Sánchez de Dios, R. \& Sáinz Ollero, H. -2008 - Effects of climate change on the distribution of Iberian tree species - Appl. Veg. Sci. 11: 169-178.

Bélisle, M. - 2005-. Measuring landscape connectivity: the challenge of behavioral landscape ecology - Ecology 86: 1988-1995.

Blanca, G., Cabezudo, B., Cueto, M., Salazar, C. \& Morales Torres, C. - 2011 - Flora vascular de Andalucía oriental, 2nd ed. - Univs. Almería, Granada, Jaén y Málaga, Granada.

Braun-Blanquet, J. - 1979 - Fitosociología. Bases para el estudio de las comunidades vegetales - Ed. Blume, Madrid.

Bright, P.W. - 1998- Behaviour of specialist species in habitat corridors: arboreal dormice avoid corridor gaps - Anim. Behav. 56: 1485-1490.
Broennimann, O., Thuiller, W., Hughes, G., Midgley, G.F., Robert-Alkemades, J.M. \& Guisan, A. -2006- Do geographic distribution, niche property and life form explain plants' vulnerability to global change? - Glob. Change Biol. 12: 1079-1093.

Calsbeek, R., Thompson, J.N. \& Richardson, J.E. - 2003Patterns of molecular evolution and diversification in a biodiversity hotspot: the California floristic province Mol. Ecol. 12: 1021-1029.

Comes, H.P. \& Kadereit, J.W. - 1998 - The effect of Quaternary climatic changes on plant distribution and evolution - Trends Plant. Sci. 3: 432-438.

Crespí, A.L., Fernandes, C.P., Castro, A., Bernardos, S. \& Amich, F. - 2007- Morpho-environmental characterization of the genus Dianthus L. (Caryophyllaceae) in the Iberian Peninsula: D. pungens gr - An. Bot. Fennici 44: 241-255.

Damschen, E.I., Haddad, N.M., Orrock, J.L., Tewksbury, J.J. \& Levey, D.J. - 2006- Corridors increase plant species richness at large scales - Science 313: 1284-1286.

Elith, J., Graham, C.H., Anderson, R.P., Dudik, M., Ferrier, S., Guisan, A., Hijmans, R.J., Hettmann, F., Leathwick, J.R., Lehmann, A., Lucia, J.L., Lohman, G., Loiselle, B.A., Manion, G., Moritz, C., Nakamura, M., Nakazawa, Y., Overton, J.M.C., Towsend Peterson, A., Philips S.J., Richardson, K., Scachetti-Pereira, R., Schapire, R.E., Soberón, J., Williams, S., Wisz, M.S. \& Zimmermann, N.E. - 2006- Novel methods improve prediction of species distributions from occurrence data - Ecography 29: 129-151. 
Elith, J. \& Leathwick, J.R. - 2009- Species distribution models: ecological explanation and prediction across space and time - Annu. Rev. Ecol. Evol. Syst. 40: 677-697.

Engler, R., Guisan, A. \& Rechsteiner, L. -2004- An improved approach for predicting the distribution of rare and endangered species from occurrence and pseudo-absence data - J Appl. Ecol. 41: 263-274.

Ferrier, S., Watson, G., Pearce, J. \& Drielsma, M. -2002Extended statistical approaches to modeling spatial pattern in biodiversity in northeast New South Wales. I. Species-level modeling - Biodivers. Conserv. 11: 22752307.

Fielding, A.H. \& Bell, J.F. - 1997- A review of methods for the assessment of prediction errors in conservation presence/absence models - Environ. Conserv. 24: 38-49.

Frajman, B. \& Oxelman, B. -2007- Reticulate phylogenetics and phytogeographical structure of Heliosperma (Sileneae, Caryophyllaceae) inferred from chloroplast and nuclear DNA sequences - Mol. Phylog. Evol. 43: 140-155.

Giménez, E., Melendo, M., Valle, F., Gómez-Mercado,F. \& Cano, E. - 2004 - Endemic flora biodiversity in the south of the Iberian Peninsula: altitudinal distribution, life forms and dispersal modes - Biodivers. Conserv. 13: 2641-2660.

Gómez, A., Lunt, D.H. - 2007- Refugia within refugia: patterns of phylogeographicconcordance in the Iberian Peninsula - In: Weiss, S., Ferrand, N. (Eds.). Phylo-geography of Southern European Refugia. Pp. 155-188. Springer, Berlin.

Guisan, A. \& Theurillat, J.P. - 2000- Assessing alpine plant vulnerability to climate change: a modeling perspective - Integr. Assess. 1: 307-320.

Guisan, A. \& Thuiller, W. - 2005- Predicting species distribution: offering more than simple habitat models Ecol. Lett. 8: 993-1009.

Gutiérrez Elorza, M. - 1994- Introducción a la geomorfología española - In: Gutiérrez Elorza, M. (Ed.). Geomorfología de España. Pp. 1-122. Ed. Rueda, Madrid.

Gutiérrez Larena, B., Fuertes Aguilar, J. \& Nieto Feliner, G. -2002 - Glacial-induced altitudinal in Armeria (Plumbaginaceae) inferred from patterns of chloroplast DNA haplotype sharing - Mol. Ecol. 11: 1965-1974.

Gutiérrez, J.M. \& Pons, M.R. -2006- Numerical Modeling of Climate Change: Scientific basis, Uncertainties and Projections for the Iberian Peninsula - Rev. C\&G 20: $15-28$.

Guzmán, B. \& Vargas, P. -2009- Long-distance colonization of the Western Mediterranean by Cistus ladanifer (Cistaceae) despite the absence of special dispersal mechanisms - J. Biogeogr. 36: 954-968.

Harrison, P.A., Berry, P.M., Butt, N. \& New, M. - 2006Modelling climate change impacts on species distributions at the European scale: implications for conservation policy - Environ. Sci. Policy 9: 116-128.

Hernández-Santana, V., Martínez-Fernández, J., Morán, C. \& Cano, A. - 2008- Response of Quercus pyrenaica (melojo oak) to soil water deficit: a case study in Spain — Eur. J. Forest Res. 127: 369-378.

Hewitt, G.M. - 1996 - Some genetic consequences of ice ages, and their role in divergence and speciation - Biol. J. Linn. Soc. 58: 247-276.

Hewitt, G.M. - 1999 - Post-glacial re-colonization of European biota - Biol. J. Linn. Soc. 68: 87-112.

Hewitt, G.M. - 2004- Genetic consequences of climatic oscillations in the Quaternary - Philos. T. Roy. Soc. B 359: 183-195.

Hopper, S. \& Gioia, P. - 2004 - The Southwest Australian floristic region: evolution and conservation of a global hot spot of biodiversity - Annu. Rev. Ecol. Evol. Syst. 35: 623-650.

Huntley, B., Berry, P.M., Cramer, W. \& McDonald, A.P. $1995-$. Modelling present and potential future ranges of some European higher plants using climate response surfaces - J. Biogeogr. 22: 967-1001.

Jetz, W., Rahbek, C. \& Colwell, R.K. -2004 - The coincidence of rarity and richness and the potential signature of history in centers of endemism - . Ecol. Lett. 7: 1180-1191.

Jongman, R.H.G., Külvik, M. \& Kristianen, I. -2005European ecological networks and greenways - Landscape and Urban Plan. 68: 305-319.

Jump, A.S., Hunt, J.M., Martínez-Izquierdo, J.A. \& Peñuelas, J. - 2006a - Natural selection and climate change: temperature-linked spatial and temporal trends in gene frequency in Fagus sylvatica - Mol. Ecol. 15: 34693480 .

Jump, A.S., Hunt, J.M. \& Peñuelas, J. - 2006b - Rapid climate change-related growth decline at the southern range edge of Fagus sylvatica - Glob. Change Biol. 12: 2163-2174.

King, R.A. \& Ferris, C. - 1998- Chloroplast DNA phylogeography of Alnus glutinosa (L.) Gaertn - Mol. Ecol. 7: 1151-1161.

Kruckeberg, A.R. \& Rabinowitz, D. -1985- Biological aspects of endemism in higher plants - Annu. Rev. Ecol. Syst. 16: 447-479.

Lobo, J.M., Castro, I. \& Moreno, J.C. - 2001 - Spatial and environmental determinants of vascular plant species richness distribution in the Iberian Peninsula and Balearic islands - Biol. J. Linn. Soc. 73: 233-253.

Médail, F. \& Quezel, P. - 1997- Hot-Spots Analysis for Conservation of Plant Biodiversity in the Mediterranean Basin - Ann. Mo. Bot. Gard. 84: 112-127.

Médail, F. \& Diadema, K. -2009- Glacial refugia influence plant diversity patterns in the Mediterranean Basin - J. Biogeogr. 36: 1333-1345.

Mejías, J.A., Arroyo, J. \& Marañón, T. -2007- Ecology and biogeography of plant communities associated with the post Plio-Pleistocene relict Rhododendron ponticum subsp. baeticum in southern Spain - J. Biogeogr. 34: 456-472.

Moreno, J.C. \& Saínz Ollero, H. - 1997- Nuevo ensayo fitogeográfico a partir de las monocotiledóneas endémicas Ibero-Baleáricas - An. Jard. Bot. Madrid 55: 351366 . 
Moreno Saíz, J.C., Castro Parga, I. \& Sainz Ollero, H. 1998 - Numerical analyses of distribution of Iberian and Balearic endemic monocotyledons. J. Biogeogr. 25: 179-194.

Nieto Feliner, G. - 2011 - . Southern European glacial refugia: A tale of tales - Taxon 60: 365-372.

Nieto Feliner, G. - 2014- Patterns and processes in plant phylogeography in the Mediterranean Basin. A review - Persp. Plant Ecol. Evol. Sys. 16: 265-278.

Oldfield, F. - 2005 - Environmental change. Key issues and alternative approaches - Cambridge Univ. Press, Cambridge.

Olalde, M., Herrán, A., Espinel, S. \& Goicoechea, P.G. 2002 - White oaks phylogeography in the Iberian Peninsula - Forest Ecol. Manag. 156: 89-102.

Olesen, H. - 1995 - Properties and units in the clinical laboratory sciences I. Syntax and semantic rules (IUPAC-IFCC Recommendations 1995) - Clin. Chim. Acta 245: 5-21.

Pardo, C., Cubas, P. \& Tahiri, H. - 2008- Genetic variation and phylogeography of Stauracanthus (Fabaceae, Genistae) from the Iberian Peninsula and northern Morocco assessed by chloroplast microsatellite (CPSSR) markers - Am. J. Bot. 95: 98-109.

Peñuelas, J. \& Boada, M. - 2003 - A global change-induced biome shift in the Montseny mountains (NE Spain) - Glob. Change Biol. 9: 131-140.

Peterson, A.T., Papes, M. \& Eaton, M. -2007- Transferability and model evaluation in ecological niche modeling: a comparison of GARP and Maxent - Ecography 30: 550-560.

Petit, R.J., Csaikl, U.M., Bordács, S., Burg, K., Coart, E., Cottrell, J., van Dam, B., Deans, J.D., Dumolin-Lapègue, S., Fineschi, S., Finkeldey, R., Gillies, A., Glaz, I., Goicoechea, P.G., Jensen, J.S., König, A.O., Lowe, A.J., Madsen, S.F., Mátyás, G., Munro, R.C., Olalde, M., Pemonge, M.H., Popescu, F., Slade, D., Tabbener, H., Taurchini, D., de Vries, S.G.M., Ziegenhagen, B. \& Kremer, A. $-2002-$ Chloroplast DNA variation in European white oaks phylogeography and patterns of diversity based on data from over 2600 populations - Forest Ecol. Manag. 156: 5-26.

Phillips, S.J. - 2010 - Species' Distribution Modeling for Conservation Educators and Practitioners, Exercise - Am. Mus. Nat. His. Les. Conserv. http://ncep.amnh.org/linc.

Phillips, S.J., Dudík, M. \& Schapire, R.E. -2004- A maximum entropy approach to species distribution modelling In: Proceedings of the 21st International Conference on Machine Learning. Pp. 655-662. ACM Press, New York.

Phillips, S.J., Anderson, R.P. \& Schapire, R.E. - 2006Maximum entropy modeling of species geographic distributions - Ecol. Model. 190: 231-259.

Puigdefábregas, J. \& Mendizabal, T. - 1998 - Perspectives on desertification: western Mediterranean - J.Arid Environ. 39: 209-224.

Ramirez, J. \& Jarvis, A. - 2008 - High Resolution Statistically Downscaled Future Climate Surfaces - Int. Cent. Tropical Agric., CIAT. http://gisweb.ciat.cgiar.org/GCMPage.
Randin, C.F., Dirnböck, T., Dullinger, S., Zimmermann, N.E., Zappa, M. \& Guisan, A. -2006- Are nichebased species distribution models transferable in space? - J. Biogeogr. 33: 1689-1703.

Rivas-Martínez, S. - 1987- Nociones sobre fitosociología, biogeografía y bioclimatología, pp. 19-45 - In: Peinado Lorca, M. \& Rivas-Martínez, S. (Eds.). La vegetación de España. Col. Aula Abierta, Univ. Alcalá de Henares, Alcalá de Henares.

Rivas-Martínez, S. \& Rivas-Sáenz, R. -2009- Worldwide bioclimatic classification system. Univ. Complutense \& Phytosoc. Res. Cent., Madrid. http://www.globalbioclimatics.org

Rocha, J., Crespí, A.L., García-Barriuso, M., Kozlowski, G., Almeida da Silva, R., Honrado, J., Talavera, S. \& Amich, F. -2012a - Morpho-environmental characterization of the genus Baldellia Parl. (Alismataceae) in the Iberian Peninsula, Balearic islands and North Morocco - Plant Biosyst. 146: 334-344.

Rocha, J., Crespí, A.L., Almeida da Silva, R. \& Amich, F. 2012b - Silene section Cordifolia in the Iberian Peninsula: a menaced group under global environmental changes? Status and conservation - Plant Ecol. Diver. 5: 45-56.

Rodríguez, J.P., Brotons, L., Bustamante, J. \& Seoane, J. 2007 - The application of predictive modelling of species distribution to biodiversity conservation - Divers. \& Distrib. 13: 243-251.

Rodríguez-Sánchez, F. \& Arroyo, J. - 2008 - Reconstructing the demise of Tethyan plants: climate-driven range dynamics of Laurus since the Pliocene - Glob. Ecol. Biogeogr. 17: 685-695.

Ruiz-Labourdette, D., Nogués-Bravo, D., Sainz Ollero, H., Schmitz, M.F. \& Pineda, F.D. - 2012- Forest composition in Mediterranean mountains is projected to shift along the entire elevational gradient under climate change - J. Biogeogr. 39: 162-176.

Sanz-Elorza, M., Dana, E.S., González, A. \& Sobrino, E. 2003 - Changes in the high-mountain vegetation of the central Iberian Peninsula as a probable sign of global warming - Ann. Bot. London 92: 273-280.

Stallins, J.A. -2006- Geomorphology and ecology: unifying themes for complex systems in biogeomorphology - Geomorphology 77: 207-216.

Swanson, F.J., Kratz, T.K., Caine, N. \& Woodmansee, R.G. - 1988 - Landform effects on ecosystem patterns and processes. Geomorphic features of the earth's surface regulate the distribution of organisms and processes BioScience 38: 92-98.

Taberlet, P., Fumagalli, L., Wust-Saucy, A.G. \& Cosson, J.F. - 1998- Comparative phylogeography and postglacial colonization routes in Europe - Mol. Ecol. 7: 453-464.

Ter Braak, C.J.E. \& Gremmen, N.J.M. -1987- Ecological amplitudes of plant species and the internal consistency of Ellenberg's indicator values for moisture - Vegetatio 69: 79-87.

Thuiller, W., Lavorel, S., Araújo, M.B., Sykes, M. \& Prentice, I.C. $-2005-$ Climate change threats to plant di- 
versity in Europe - Proc. Natl. Acad. Sci. 23: 82458250.

Tzedakis, P.C. -2007 - . Seven ambiguities in the Mediterranean palaeoenvironmental narrative - Quat. Sci. Rev. 26: 2042-2066.

Valdes, B., Talavera, S. \& Fernandez-Galiano, E. - 1987Flora vascular de Andalucia Occidental, 3 vols. - Ketres Ed., Barcelona. 555 p.

Vargas, P. - 2003 - Molecular evidence for multiple diversification patterns of alpine plants in Mediterranean Europe - Taxon 52: 463-476.

Received: 29 January 2014

Accepted: 23 October 2014
Wohlgemuth, T. - 1998 - Modelling floristic species richness on a regional scale: a case study in Switzerland Biodivers. Conserv. 7: 159-177.

Yost, A.C., Petersen, S.L., Gregg, M. \& Miller, R. -2008Predictive modeling and mapping sage grouse (Centrocercus urophasianus) nesting habitat using Maximum Entropy and a long-term dataset from Southern Oregon - Ecol. Infor. 3: 375-386.

Young, K.R., Ulloa, C., Luteyn, J.L. \& Knapp, S. - 2002Plant evolution and endemism in Andean South America: an introduction - Bot. Rev. 68: 4-21. 